In accordance with Dr Forde's expressed wishes, the resources of the Daryll Forde Memorial Fund, established a few years ago, are to be made available to the Publications Committee of the Institute to strengthen its book publishing programme.

\title{
INTERNATIONAL AFRICAN SEMINAR ON THE PROFESSIONALISATION OF AFRICAN MEDICINE
}

The Institute was delighted to be able to hold the first of its new seminars at the University of Botswana, Gaborone, 19-24 September 1983, for the first time in conjunction with the annual meeting of its Executive Council. The seminar was the first international meeting held at the University since it became formally independent and the Vice-Chancellor expressed his particular pleasure that the University had had the opportunity to welcome such a distinguished gathering. A number of seminar participants as well as Executive Council members of the Institute gave lectures and met with students at the University during our presence in Gaborone.

The seminar was opened and made welcome by the Minister of Home Affairs, the Vice-Chancellor, and the Director of the National Institute of Development Research and Documentation. Some forty-seven people from seventeen countries, twelve of which were African, attended the seminar.

The papers are being revised for publication under the editorship of Dr Last and Professor Chavunduka, and it is hoped to publish them in our usual IAI seminar format.

The Institute should like to express its particular thanks and gratitude for the support it has received enabling it to hold this meeting, from the Swedish Agency for Research in Developing Countries; Voluntary and Christian Service; the World Health Organisation; the Commonwealth Foundation; and of course the University of Botswana, its Vice-Chancellor and staff.

\section{HOUSING THE URBAN POOR IN AFRICA}

The International African Institute is presently undertaking a study on Housing the Urban Poor in Africa to provide the background paper to a proposed International African Seminar on this topic to be held in spring 1985, probably in Tunis, under the direction of Professor Peter Lloyd of Sussex University. This initial work is funded by the Social Science Research Council, London, and is being carried out by Dr Phillip Amis who has recently completed his thesis on the commercialisation of unauthorized housing in Nairobi.

The major object of this study is to give an overview and explain the variations in housing provision and tenure and approaches to 'unauthorized' settlements throughout Africa. In particular we are interested in monitoring and evaluating the changes in housing provision and responses to 'unauthorized' settlements within the last twenty years with a view to possible policy alternatives. These changes might include the following: attitudes to rural-urban migration; the emergence of the private rental sector in unauthorized settlements; the nature of access to land by the urban poor, i.e. market or invation; the legal position of unauthorized areas; the possibility of 